International Journal of Social Sciences and Humanities
Available online at http://sciencescholar.us/journal/index.php/ijssh
Vol. 3 No. 1, April 2019, pages: 36 47
e-ISSN: 2550-7001, p-ISSN: 2550-701X
https://doi.org/10.29332/ijssh.v3n1.251

\title{
Translation of Krsșa Text and Ideology
}

\author{
(1) crossarak \\ I Wayan Suryasa ${ }^{a}$, I Nengah Sudipa ${ }^{\text {b }}$, Ida Ayu Made Puspani ${ }^{c}$, I Made Netra ${ }^{\mathrm{d}}$ \\ Article history: Received 27 August 2018, Accepted: 31 December 2018, Published: 1 March 2019
}

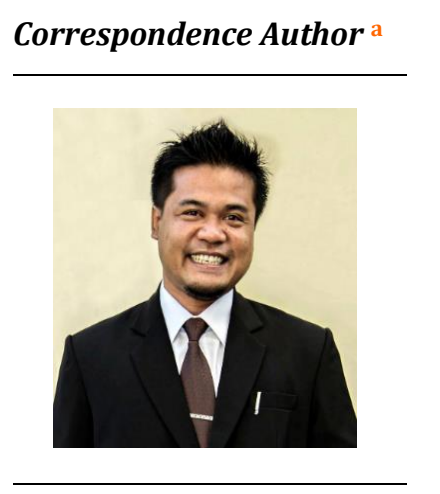

Keywords

domestication:

emotion;

ideology;

Krșna text;

translation;

\begin{abstract}
The recent interest in the relation between translation and ideology led to the following research based on the translation of Krșna text. The Indian short story for Krșna; The Supreme Personality of Godhead and its translation for Krșna: Personalitas Tuhan Yang Maha Esa (English to Indonesia) to highlight how the translation ideology applied in transferring the meaning of emotions. If external influences cannot be avoided, a translation should respect its main scope of being the source for a cultural change. Therefore, the two questions that have eventually to be answered are how does the translation ideology related to the word of emotions in the common culture reader. Reasoning about the factors underlying the translation ideology applied towards Indonesian culture.
\end{abstract}

e-ISSN: 2550-7001, p-ISSN: 2550-701X ${ }^{\odot}$ Copyright 2019. The Author. SS Journals Published by Universidad Técnica de Manabí. This is an open-access article under the CC BY-SA 4.0 license

(https://creativecommons.org/licenses/by-sa/4.0/)

All rights reserved.

\section{Contents}

Abstract.

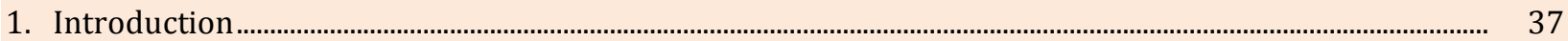

2. Materials and Methods ............................................................................................................................................... 38

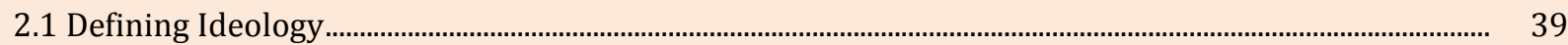

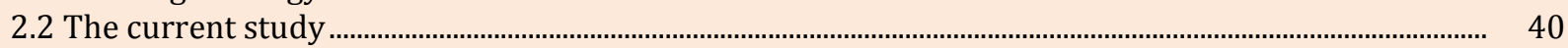

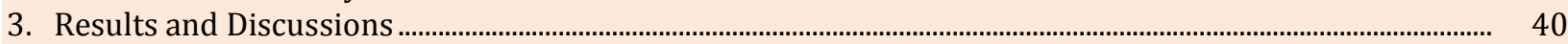

3.1 Translation of Krṣṇa Text and Ideology .............................................................................................................. $\quad 41$

3.2 Factors towards the Ideology of Translation ....................................................................................................... $\quad 42$

a STIKOM Bali, Department of Computer System, Denpasar, Indonesia ID 80226 Ph. +6281338734500

b Udayana University, Faculty of Art, Denpasar, Indonesia, ID 80234 Ph. +628124667921

c Udayana University, Faculty of Art, Denpasar, Indonesia, ID 80234 Ph. +6281239351550

d Udayana University, Faculty of Art, Denpasar, Indonesia, ID 80234 Ph. +6281337291620 
3.3 Novelty in Methodology.

4. Conclusion

Acknowledgements..

References

\section{Introduction}

Language and culture are two things that cannot be separated from each other if they are related to the meaning contained in them. Language is a tool to convey meaning or message (Wierzbicka, 1996: 144). The structure of the tool is able to reflect the functions is more easily understood in certain terms that are in accordance with their functions. Therefore, to learn the language must also be understood the meaning implied in the form and sign as the physical form of the language itself. Saussure (1995: 34), stated that Language is a sign system that is able to express the ideas of the human mind.

Regarding the rationally pragmatic, the practical term in the current study is to consider a concept of emotion. Emotions cannot be separated from a culture (Wierzbicka, 1986). The practical matters referred to phenomena that occurred in the culture of social life. For example, the culture in the Source Language (SL) is very expressive compared to the culture found in the Target Language (TL). Related to the two different cultures this is also a reason why research on the concept of the meaning of emotions is very important to study in order to find out what happened to the translation product. Discussing regarded the concept of emotions cannot be separated from the concept of feeling.

According to a biologist, Birch (1995), feelings are something that is dominant in life or only agreement of an agreement of the heart as a determinant of feeling. Some people don't say feelings but emotions. So the question, which one is used? Biologically the words feelings are acceptable and will be accepted again with the term emotions which are very closely related to language and culture (Kramsch \& Widdowson, 1998). However, the word emotion is used because it looks more objective with the interpretation that only an objective is real and acceptable to study in a study. This research empirically is also motivated by several previous researcher's thoughts that examine the meaning of emotions about translation.

The Krṣna text is phenomenal, unlike translation, it is very interesting to study due to the content of the textbook has a strong philosophy of life, full of norms, manners, and can be used as guidance in life. On the one hand, the Krșna text has many meanings of emotion both positive emotions and negative emotions. On the other hand, it is also seen the linguistic phenomena, from various emotions in the life of language and culture. Having seen the model of the translation of meanings of emotions to the varied Krṣna texts, it is also important for researchers to examine the ideology adopted in its translation. The phenomena such as the translation of meanings of emotions included positive to positive, positive to negative, negative to negative, negative to positive or neutral. Regarding the phenomenon, it is also able to change one's character as a result of the text they read. Therefore, it is very necessary and important for researchers to be able to understand more deeply by examining the emotion of English-Indonesian into the translation of Krșna text.

The phenomenon of translation in the Krșna text involves the transfer of cross-cultural meanings. Crosscultural in question is the culture that exists in India with the culture that exists in Indonesia. Finding out the meaning or message that exists in the SL requires further study, especially on words of emotions. This research has been conducted based on the paradigm of thinking to identify translation procedures applied by the translator in transferring meanings of emotions from English into Indonesian. Identification of translation procedures is a study at the micro stage (word) in this study. Therefore, a theory is needed as a tool to identify translation procedures. The theory of Vinay \& Darbelnet in Venuti (2000: 84), is considered capable of identifying translation procedures that are applied to produce a translation work.

It is important to identify the translation of procedures and methods in order to be able to identify the applied of the translation ideology. An ideology becomes useful if the translator is able to understand both the culture that exists in the target culture as well as the culture that is in the reader. Reasoning how does the translation ideology related to the word of emotions in the common culture reader and about the factors underlying the translation ideology applied towards Indonesian culture.

Suryasa, I. W., Sudipa, I. N., Puspani, I. A. M., \& Netra, I. M. (2019). Translation of Krșna Text and Ideology. International Journal of Social Sciences and Humanities, 3(1), 36-47. https://doi.org/10.29332/ijssh.v3n1.251 


\section{Materials and Methods}

This is qualitative research that the data collection taken from the Indian short story for Krșna; The Supreme Personality of Godhead and its translation for Krșna: Personalitas Tuhan Yang Maha Esa (English to Indonesia). The textbook of the data source is presented in Figure 1.

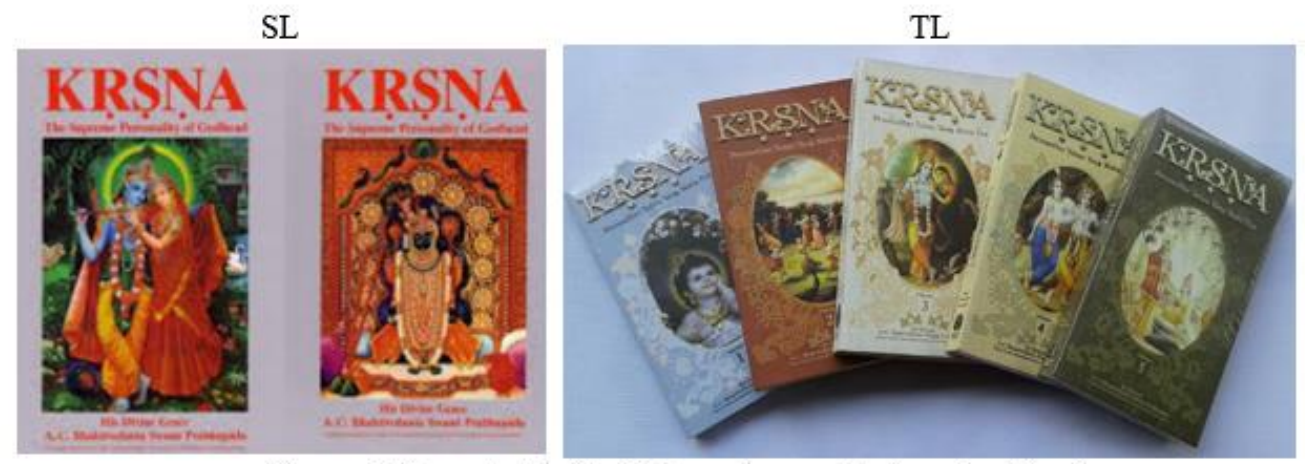

Figure 1. Krsna text in English version and Indonesian Version

In order to identify the translation procedures of the meaning of emotions as the smallest unit of translation is presented in Figure 2.
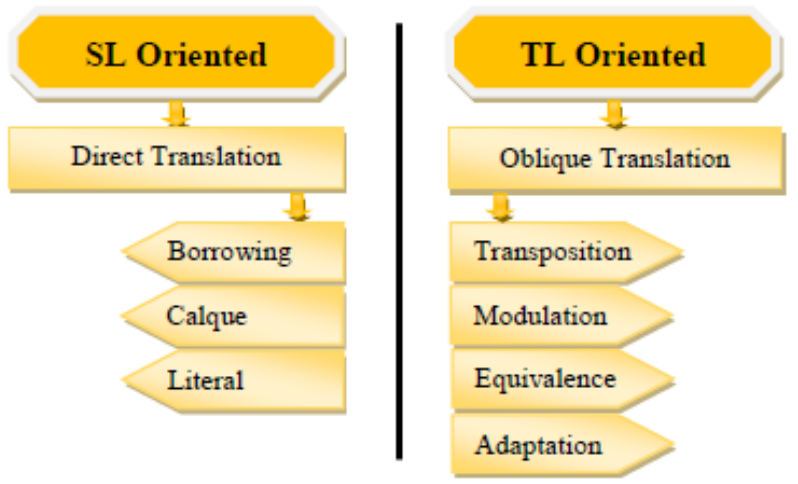

Figure 1. The procedure of direct and oblique translation (Vinay and Darbelnet, 2000)

Regarding the translation method applied based on the identified translation procedure. Identifying the method refers to the whole text is presented in Figure 3.

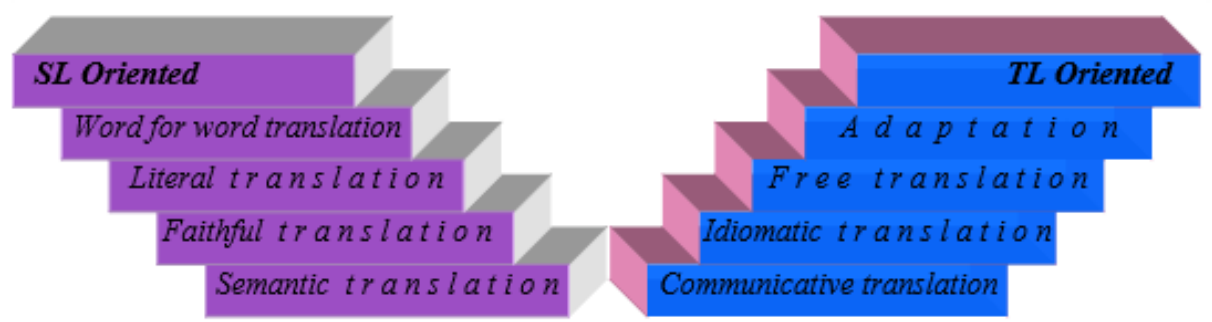

Figure 3. V diagram for translation methods (Newmark, 1998: 45)

Describing the translation ideology find in the Kṛṣna text applied the theory from Hatim \& Mason (2005) is presented in Figure 4. 


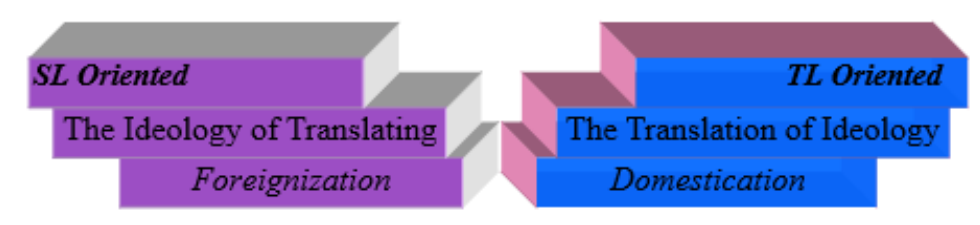

Figure 4. Domestication and foreignization (Hatim \& Mason, 2005)

\subsection{Defining Ideology}

Ideology can be stated as an understanding or belief which is believed to be the truth. This can be seen from the existence of communism, liberalism, and others as ideology. Ideology can be either abstract or real (Hatim \& Mason, 1997: 119). According to Hoed (2003: 4), the ideology of translation is a principle or belief about right or wrong in translation.

The ideology referred to the current study is a translation perspective related to the orientation applied. The translation orientation can adhere to the SL system or in accordance with the text in the TL. The perspective intended, here, is a translation to be proper, if the translation text has conveyed the SL text message into the TL text correctly. The perspective of right or wrong can be seen from the aspect of acceptance that is high or low. Acceptance aspects are interpreted as translation texts that fulfill the SL both grammatical and cultural rules (Baker, 2003).

The orientation of the translation ideology intended in this study is a belief about right and wrong in translation including the method carried out by the translator, namely foreignization and domestication. Xiaoning \& Cheng (2003), suggests that the term foreignization and domestication is used to refer to the method applied by the translator when transferring a text from a language into another language. The translation is stated to be good if the translation refers to the SL. Therefore, a translation text is stated to be good, if it can be accepted and well understood by the TL readers. The text of the translation must not sound like a translation text, as if it were an original work of the language in question. Conversely, the translation is good, if the translation refers to the TL or retains the SL forms including cultural elements.

Hatim \& Mason (2005), such issues of ideology in translating will occupy us, where the two texts are discussed in greater detail. Suffice it here to say that some interesting divergences are readily apparent when source and target texts are compared and different world views or ideologies emerge. Also implicated are intentionality, socio-cultural and socio-textual practices and the realization of these in the actual texture and structure of texts. Instead, an analytical orientation is deliberately adopted: reference to people is avoided as far as possible (e.g. reports indicate), nominalizations are preferred to straightforward agent-verb sequences (a slaughtering operation), and verbs of perception, feeling, etc. are rarely used. The overall effect is a world interpreted in new ways to accommodate an ideology under threat (Martin, 1985).

Since translators have a role to play in the way language ultimately evolves in social life (language planning, influence on lexical change, etc.), examining the multifaceted phenomenon of text type in communicative practice is something which translation theory cannot afford to ignore. Factors such as politeness, power, and ideology have a role to play in the choices we make ranging from the smallest to the largest unit of linguistic expression. The use of texts is thus imbued with discoursal meaning, a phenomenon which will be at the center of the following discussion (Hatim \& Mason, 2005).

Having appreciated the ways in which textual strategy is closely bound up with cultural beliefs, values, and expectations, we now turn our attention to ideology and the ways in which it impinges upon the work of the translator. Such a concern is not new. Hermans (1985), Bassnett \& Lefevere (1990), offer evidence of ideology at work in literary translating; Venuti (1995), shows the considerable consequences of translator's basic orientation.

Kress (2009), Fairclough (1989) and others, the insights provided by these studies advance our understanding of the way ideology shapes discourse and the way discourse practices help to maintain, reinforce or challenge ideologies. A fundamental distinction needs to be made from the outset. What follows is divided into (1) the ideology of translating and (2) the translation of ideology. That these two issues are closely related will be apparent to anyone who has, for example, reviewed the practice of (official) translators

Suryasa, I. W., Sudipa, I. N., Puspani, I. A. M., \& Netra, I. M. (2019). Translation of Krșna Text and Ideology. International Journal of Social Sciences and Humanities, 3(1), 36-47. https://doi.org/10.29332/ijssh.v3n1.251 
under totalitarian regimes. The extent of the translator's mediation is itself an ideological issue, affecting both, (1) and (2) (Hatim, 1999: 119).

\subsection{The current study}

The translator at the time is dealing with forms or terms or anything from source language texts that require special consideration whether the translator must maintain the form as contained in the SL because certain considerations or must change to make it easier for the reader to understand by making something closer to readers. It is in a position to have to decide whether domestication or foreignization. It can be stated simply that the translation orientation can adhere to the SL system or to the TL culture.

Hatim (2000), argued that ideology in translating is not only based on the perspective of critical discourse analysis but also based on the perspective of cultural studies. Research on translation and ideology have two different perspectives that must be determined in advance, including:

(1) The ideology of translating focuses on how the ideology of the text to be translated is confronted with and how best to convey it into a translation. Regarding this perspective, various discursive forms in a text are focused. Some of the obstacles tend to be related to this; the use of language in social life, including values, a belief system that has been known by a group of individuals in a particular social group. Examples: racism and feminism. Therefore, it tends to express the culture of the SL into TL.

(2) The translation of ideology; this ideology becomes a term that includes something most basic not only in the text or translation but also what is contained in the text and the translation. Some obstacles, in this case, are the text in the SL can be translated into TL. It means that a text in the SL can be translated into TL with a traditional approach. Based on these two differences, a significant problem is a principle which the translator must use in the process of translating a text. Translator mediation is ideological namely; the translation of ideology is translated as feminism or regime oriented to TL culture or tradition while the ideology of translating is a translator in translating oriented to SL based on its tradition. In addition to culture and tradition, which also plays a role, in this case, is the perspective of the values and belief systems adopted.

Albrecht (1997), suggested ideology is assumptions, beliefs and value systems; it held collectively by a particular society or social group. Hatim (2001: 230), defining ideology is a principle adopted by a person or group of people and the mindset that is adopted cannot be separated from the cultural values they have. Ideology becomes the basis for thinking, acting, and behaving. Any ideology adopted by a person or group of people (e.g., political, economic, religious, social and cultural behavior) will be realized through linguistic behavior. One language behavior is realized through translation behavior or translation ideology.

Based on its orientation, Hatim (2001: 229-230), divided the ideology into two, namely; (a) Foreignization defines the translations that intentionally violate target conventions by retaining something unknown from foreign texts, (b) Domestication defines the transparent translation, by adopting a fluent style to minimize strangeness in foreign texts. The (a) and (b) tendencies can be stated as mediation or intervention of the translator in the translation process, oriented translator. Thus, the reader is closer to the message conveyed by the author is called foreignization, and conversely, the translator oriented to the author to be closer to the reader is called domestication (Hatim \& Mason, 1997: 146; Hatim, 2001: 46).

\section{Results and Discussions}

There are seven translation procedures (Venuti, 2012), that are applied in translating the meaning of English emotions into Indonesian in the Krșna text. In addition, there are also eight translation methods (Newmark, 1998), adopted by the translator in carrying out their duties to produce a product of translation.

The current research presents the results of research on the ideology that is applied in translating. The systematic presentation of the results of the study is based on several rational considerations. First, the smallest unit of translation is the meaning of emotion which is essentially a word or phrase at the micro level. Meaning of emotions in the form of words or phrases is then analyzed and classified to find out the translation procedures applied by the translator in dealing with equivalence problems. Second, the results of research concerning the translation procedure are then used as a basis for expressing the translation of method as a global choice that affects the entire translation text. Third, only after the translation procedures and 
translation methods can be properly identified, this section can present ideology as a belief system in making decisions that are interpreted by the translator in producing a translation product.

\subsection{Translation of Kṛșna Text and Ideology}

It involves seven translation procedures that are applied in identifying the meaning of English emotions. It is included (1) borrowing (2) calque (3) literal (4) transposition (5) modulation (6) equivalence and (7) adaptation. Towards the seven translation procedures that have been identified; there are only four procedures applied included (1) borrowing (2) literal (3) transposition and (4) modulation. The translation procedure partiality determines the translation method applied by the translator. This can be described and it is presented in Figure 5.

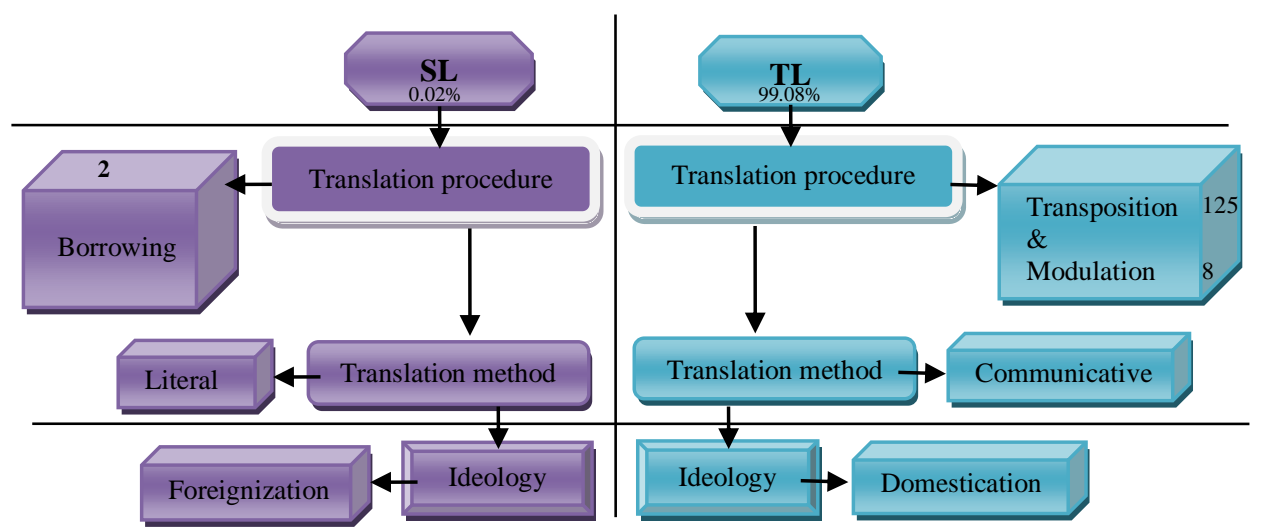

Figure 5. The orientation of procedures, methods, and ideologies for translating the meaning of English emotions into Indonesian in the Kṛșna text

The translation procedure takes into consideration the rules, norms, and culture that apply in the TL (Schäffner, 2004). The meanings of English emotions with their parameters of scenario cognitive were not freely translated into Indonesian. Several choices are available, but carefulness is needed in determining one of the options that best fits the culture of Indonesian people who are very concerned about the message that the translator can deliver in a product of translation. This is highly considered the Krșna text is a text that is very thick with nuances of spirituality and belief.

Thus, communism, fascism, anarchism and so on would qualify as ideologies in this scheme of things while liberal democracy, presumably, would not. In a similar way, some political moves or measures are said to be 'ideologically motivated', as if others were not. Such an acceptation of the term is of no use to the linguist, from whose perspective all use of language reflects a set of user's assumptions which are closely bound up with attitudes, beliefs, and value systems. Consequently, with Simpson (1993: 5), the ideology shall define as the tacit assumptions, beliefs, and value systems which are shared collectively by social groups. Rather, we prefer to assume that a two-way process is involved, in which users are at one and the same time an active subject (agent) in the discourse, and passively subjected to its authority (Gee, 2007: 174).

Nabokov (1964), famous tirade against free translating is characteristic of the terms in which the debate has been set. Many writers have seen translators options as lying between two polarities free versus literal, dynamic equivalence versus formal equivalence (Nida, 1964); communicative versus semantic translating (Newmark, 1981). The studies of translation from the point of view of critical discourse analysis (Knowles \& Malmkjaer, 1989) analyzed four translations into English of Hans Christian Andersen's fairytale Den Standhaftige Tinsoldat ('The Steadfast Tin Soldier'). The evaluative adjective stand-haftige which appears in the title appeals to values which are, at one and the same time, central to the moral import of Andersen's story (the tin soldier remains steadfast throughout many trials and tribulations caused by an unjust world) and shared by both Danish and English-language traditional value systems (the moral value of remaining steadfast in adversity). Yet the translation of this term is problematic.

Suryasa, I. W., Sudipa, I. N., Puspani, I. A. M., \& Netra, I. M. (2019). Translation of Krșna Text and Ideology. International Journal of Social Sciences and Humanities, 3(1), 36-47. https://doi.org/10.29332/ijssh.v3n1.251 
The ideology in the translation is the perspective of the translator to determine orientation. This orientation cannot be separated from the culture embraced by translation, whether the translator adheres to a culture system oriented to the SL or the TL. Based on Figure 5 above the translator uses the TL cultural system. The method applied is mostly transposition. This method allows translators to determine their point of view in producing a product of translation that is easily understood by readers.

In the translation of ideology, there are two opposite poles. One polar is leaning on the source language while the other polar is leaning on the target language. The translators will always be faced with these two choices. Choosing to maintain a foreign culture or term means being more inclined to the source language or by Venuti (2012), is called foreignization. Choosing to use target language means tending to culture or the term target language, by Venuti (2012), called domestication. In order to produce a good translation work and accept an interpreter in making decisions, it may be based on his/her ideology, publisher pressure, or desire to meet the tastes of the reader. In this case, the translator intervenes in the translation process. Translators have a tendency to determine one choice from the two opposite poles, namely foreignization or domestication.

Figure 5 above shows that, on the one hand, there is two orientation of the translation procedures. The translation procedure is applied borrowing and literal translation method. The method is based on foreignization ideology. On the other hand, there are two translation procedures that are BT oriented. The two translation procedures are the realization of the applied of the communicative method. The application of the method of communicative translation is based on domestication ideology. Thus, it can be explained that there are two applied translation ideologies namely foreignization and domestication. From the diagram above it can be concluded that the tendency for the translator to apply domestication ideology.

\subsection{Factors towards the Ideology of Translation}

Culture is the most fundamental thing in the world translation, due to the chosen cultural approach determines the way of thinking and perspective of translation. The concept of culture must be understood before starting the translation process. Venuti (1995), described there are two perspectives on a culture with the concept of foreignization and domestication. These concepts are related to the culture that is in the SL and TL.

Venuti (1995: 20), observed the product of translation in two countries i.e., America and France tended to apply domestication as a result of differences in language and culture. Domestication has been practiced since Roman times, the translation was used as a means of colonialism by using Roman cultural concepts to conceptualize Latin culture. The implications of differences in language and culture require translators to choose between domestication and foreignization. Domestication as a translator's point of view in adhering to a certain belief system where the translator is oriented to the SL cultural system, which is, of course, all kinds of expressions, semiotics can be expressed in the TL based on the culture in Indonesia. Meanwhile, foreignization as the SL oriented translator" point of view, the translation text contains many features of the SL and the introduction to the target reader.

The first concept of placing the translator in full is under the control of the author of the SL text. Therefore, the translator becomes invisible Venuti (1995). The translation text tends to present cultural nuances that are in the target reader because of the conception that adheres to the TL cultural system. This cultural selection has made it easier for readers to understand the contents of the translation text because of the nuances of the emotional texts presented at the TL according to their culture. Domestication is a choice of cultural concepts that translators will apply to produce a translation product.

The translation of ideology applied by the translator cannot be separated from a cultural system. The cultural system that is in the SL text and also the cultural system that is in the target reader. Based on the phenomenon in the translation of Krșna text, there are several factors that underlie the application of the translation of ideology, in term of this, is domestication. This factor uses the $3 C$ model, namely content, context, and communication.

First, content in the SL text is a story that tells from the beginning to the end of a belief in Krșna as the supreme personality of Godhead. The overall story content expresses the culture that exists in India. Indian culture is very thick with certain beliefs. This belief is carried out on certain days depending on the god whom the ceremony is intended. They believe that every god is able to describe happiness in birth and concern. Krșna also was known as Janmashtami or Gokulashtami is an annual Hindu festival that celebrates the birth of 
Krșna, the eighth Awatara of Lord Vishnu. This is observed according to the Hindu lunisolar calendar, on the eighth day (Ashtami) of Krishna Paksha (two dark weeks) in Shraavana of the Hindu calendar and Krishna Paksha in Bhadrapad of the lunisolar Hindu calendar, which overlaps with the August and September Gregorian calendar.

This is an important festival, especially for the Hindu Vaishnavism tradition. Dance dramas from Kṛșna's life according to the Bhagavata Purana, devotional songs at midnight when Kṛșna is believed to have been born, fasting (upavasa), midnight (jagarana), and a festival (mahotsava) the next day are part of Krșna's celebration.

The translators must also understand the content of Krssna who was born in an era of chaos, rampant persecution, freedom is denied, evil is everywhere, and when there is a threat to his life by his uncle, King Kansa. This moment is celebrated by singing devotional songs of love for Kṛ̦na, and staying awake at night.

Second, the context in the Krșna text involves situations that exist in that period. This situation reflects the culture embraced by the people in India. The reflections that contain the philosophical elements exist in every chapter of the Krsnna text. A translation work must re-express the meaning or message consisted of the SL. A good understanding of the SL is the main capital for the translator's to determine an ideology which is an option to create quality translation results. The context shown more in the Krșna BS text is the feel of positive emotions. The nuances of positive emotions can make people tend to think well. Good thinking is expected to be able to create an atmosphere, nuance, situation, and conditions that are conducive and beneficial to others.

The basic simple context that the translator deserves to understand is the birth ritual of Krșna which is celebrated with devotion and enthusiasm in India, in Indonesia around July or August. Kṛșna is considered to be one of the most powerful human incarnations of Lord Vishnu. The only purpose of Kṛsna's birth is to free the earth from evils. He played an important role in the Mahabharata and spread the devotional theory and good karma that was told in depth in the Bhagavad Gita. The Krșna ritual is celebrated with devotional songs and dances, praying, meanings, snail blows, and Krșna's baby dance.

This context can determine the choice of the ideology of a translator and it has been identified that translators tend to apply cultural systems in Indonesia. The basic context that the translator must understand is known that the Krșna story is in an Indian country which is a Hindu State. They do not have a nationally recognized religion but they have a belief in the gods who are believed to be able to describe the gift of happiness born and are concerned, the world, and the hereafter.

Third, communication, in this case, is a social practice. The social practices displayed in the Kṛsna text BS reflect a spiritual nuance that is closely related to a particular belief system. The translators must have a good understanding of the communication styles in the Krṣna text to produce a translation that has high efficiency for the target reader. The style and strategy that has been applied to the Krșna translation text adhere to a high-level cultural system. This strategy is implemented maybe on the basis that the culture in India has similarities with the culture that exists in Indonesia.

Thus, translation as a social activity cannot be separated from ideological influences. For example, if the purpose of a method of translation is to produce foreignization, borrowing would be the most frequently used translation technique. Meanwhile, due to the translation of the Kṛșa text from English into Indonesian was conducted using a communicative method, the transposition translation procedure was very dominant in applying the meaning of emotions of English into Indonesian to produce domestication. This phenomenon is also expressed by Molina \& Albir (2002), a choice of methods is strongly influenced by the purpose and function of translation and the expectations of the target readers of the translation text. The method chosen is also a guideline for translation procedures. Thus, there is a synergy between the two to produce a functional and adequate translation for the target reader. The important point is that translation work must have positive benefits for its readers.

\subsection{Novelty in Methodology}

Positive and negative emotions are two emotions that always coincide. Unlike the concept of Druwa Bhineda which is understood by the reader culture of the translation work of the Krṣna. The results of the study prove that one technique that can be applied to determine procedures, methods and translation ideology is a comparative technique. This technique is able to explain both phenomena that exist at the polar of the left or right. Therefore, the comparative technique is one of the methodologies that can be applied in

Suryasa, I. W., Sudipa, I. N., Puspani, I. A. M., \& Netra, I. M. (2019). Translation of Krșna Text and Ideology. International Journal of Social Sciences and Humanities, 3(1), 36-47. https://doi.org/10.29332/ijssh.v3n1.251 
studying deeper knowledge related to the concept of translation, in this case, the translation of ideology i.e., domestication.

\section{Conclusion}

The starting point of this paper has been the relation between translation and ideology led to the following research based on the translation of Krșna text. The Indian short story for Kr̦șna; The Supreme Personality of Godhead and its translation for Krșna: Personalitas Tuhan Yang Maha Esa (English to Indonesia) to highlight how the translation ideology applied in transferring the meaning of emotions and its translations and $3 C$ model to highlight the factor of ideology, external values and meanings in the process of translation and finally in the resulting translator s choices. Ideology cannot be avoided and translated texts are embedded with it, however, it is possible to rationalize it if the position of the translator is considered a fluctuant one which takes place at the intersection of the cultures in questions, source culture (SL), and target culture (TL). Pym (1998), has called this particular position interculturality not to be confused with cross-cultural approaches or multiculturalism. In addition, another approach, form the cognitive studies, has been taken into consideration. If the only factor that can relate the society and the discourse is the cognitive element, then this could be considered and applied in the analysis of the translation processes and choices as determined by (internal) factors. The two questions about the possibility and the way to preserve the ethics of the translation and the reader from unconscious manipulation find common ground in what has been called the education of the reader, through critical reading and foreign language teaching.

The relevance of the procedures and methods of translation applied determines the ideology of the translator in completing his/her task of creating a translation work. Procedures and translation methods that are oriented towards TL are directly proportional to the ideology applied. The proper ideology applied in translating the Krșna text is domestication. This ideology tends to try to reflect the culture of the reader as a whole. With the various explanations above, communicative methods can be formulated as a process of transferring meaning or message, in the form of emotions that consist of meaning, from the SL to the TL which involves the process of meaning.

\section{Acknowledgments}

The authors would like to thank the editor of the IJSSH for their valuable time, support, and advice in completing the present article. 


\section{References}

Albrecht, J., Arnos, F. R., Andrews, A., Shopen, T., Baker, M., Baker, M., ... \& Bassnett-Maguire, S. (1997). The Translation of Shakespeare in Malaysia. In Translation and Language: Linguistic Theories Explained (Vol. 1, No. 3, pp. ix-ix). Tübingen: Cape Goliard Press.

Baker, M. (2003). Routledge encyclopedia of translation studies. Routledge. https://doi.org/10.4324/9780203359792

Bassnett, S., \& Lefevere, A. (Eds.). (1990). Translation, history and culture (p. 10). London: Pinter Publishers. https://9jr2zyk37911.storage.googleapis.com/EgcfwLcvn8naZ9ZUR411.pdf

Birch, C. (1995). Feelings. Unsw Press. https://books.google.co.id/books?hl=en\&lr=\&id=syeu3egi6ygc\&oi

De Saussure, C., \& Muyden, V. (1995). A Foreign View of England in 1725-1729: The Letters of Monsieur César de Saussure to His Family (Vol. 2). Caliban.

Fairclough, N. (1989). Language and Power\| Longman.

Gee, J., \& Gee, J. P. (2007). Social linguistics and literacies: Ideology in discourses. Routledge. https://doi.org/10.4324/9780203944806

Hatim, B. (1997). Intertextual intrusions: towards a framework for harnessing the power of the absent text in translation. Translating sensitive texts: Linguistic aspects, https://books.google.co.id/books?hl=en\&lr=\&id=RCWS0wFUpaEC\&oi

Hatim, B. (2000). Mason. Politeness in Screen Translation. The Translation Studies Reader. Ed. Venuti, Lawrence.

Hatim, B. (2001). Mason. Discourse and the Translator, 133.

Hatim, B., \& Mason, I. (2005). The translator as communicator. Routledge. http://www.ilts.ir/content/ilts.ir/page/142/contentimage/translator\%20as\%20communcator.pdf

Hatim, B., \& Mason, I. (2014). Discourse and the Translator. Routledge. https://doi.org/10.4324/9781315846583

Hermans, T. (1985). TheManipulationof Literature-Studies in Literary Translation. New York: St. Martin's Press.

Hoed, B. H. (2003). Ideologi dalam penerjemahan. Solo: Konas Penerjemahan.

Knowles, M., \& Malmkjær, K. (1989). Translating ideology: Language, power and the world of the Tin Soldier. ELr Journal, 3, 205-242.

Kramsch, C., \& Widdowson, H. G. (1998). Language and culture. Oxford University Press. https://books.google.co.id/books?hl=en\&lr=\&id=xrpionic2pmc\&oi

Kress, G. (2009). Multimodality: A social semiotic approach to contemporary communication. Routledge. https://doi.org/10.4324/9780203970034

Martin, J. R. (1985). Teaching factual uniting: Exploring and challenging social reality. Victoria: Deakin University Press.

Molina, L., \& Hurtado Albir, A. (2002). Translation techniques revisited: A dynamic and functionalist approach.Meta: Journal des Traducteurs/Meta: Translators' Journal, 47(4), 498-512. https://doi.org/10.7202/008033ar

Newmark, P. (1981). Approaches to Translation (Language Teaching Methodology Senes). Oxford: Pergamon Press. https://doi.org/10.1017/S0272263100005222

Newmark, P. (1998). More paragraphs on translation. Multilingual matters. https://books.google.co.id/books?hl=en\&lr=\&id=3Mw6XwLHOssC\&oi

Nida, E. (1964). A (1964) Towards a Science of Translating. Leiden, EJ Brill.

Pushkin, A. S. (1964). Eugene Onegin: Translated from the Russian, with a Commentary by Vladimir Nabokov. Routledge \& Kegan Paul.

Pym, A. (2017). Exploring translation theories. Routledge. https://doi.org/10.4324/9781315857633

Schäffner, C. (2004). Metaphor and translation: some implications of a cognitive approach. Journal of pragmatics, 36(7), 1253-1269. https://doi.org/10.1016/j.pragma.2003.10.012

Simpson, P. (2003). Language, ideology and point of view. Routledge. https://doi.org/10.4324/9780203136867

Venuti, L. (1995). The Translator's Invisibility. London and New York. Routledge. New York Times "California Seeks to Stop the Use of Child Medical Interpreters, Published: October, 30, 2005.

Suryasa, I. W., Sudipa, I. N., Puspani, I. A. M., \& Netra, I. M. (2019). Translation of Krșna Text and Ideology. International Journal of Social Sciences and Humanities, 3(1), 36-47. https://doi.org/10.29332/ijssh.v3n1.251 
Venuti, L. (2012). The translation studies reader. Routledge. http://www.academia.edu/download/54919162/boundary_2-2010-Venuti-5-28.pdf

Venuti, L. (2017). The translator's invisibility: $A$ history of translation. Routledge. https://doi.org/10.4324/9781315098746

Wierzbicka, A. (1986). Human emotions: universal or culture-specific?. American anthropologist, 88(3), 584594. https://doi.org/10.1525/aa.1986.88.3.02a00030

Wierzbicka, A. (1996). Semantics: Primes and universals: Primes and universals. Oxford University Press, UK. https://books.google.co.id/books?hl=en\&lr=\&id=ZN029Pmbnu4C\&oi

Xiaoning, Y., \& Cheng, L. (2003). On Foreignization and Domestication in Translation [J]. Foreign Languages and Their Teaching, 2. http://en.cnki.com.cn/Article_en/CJFDTOTAL-WYWJ200302007.htm 


\section{Biography of Authors}

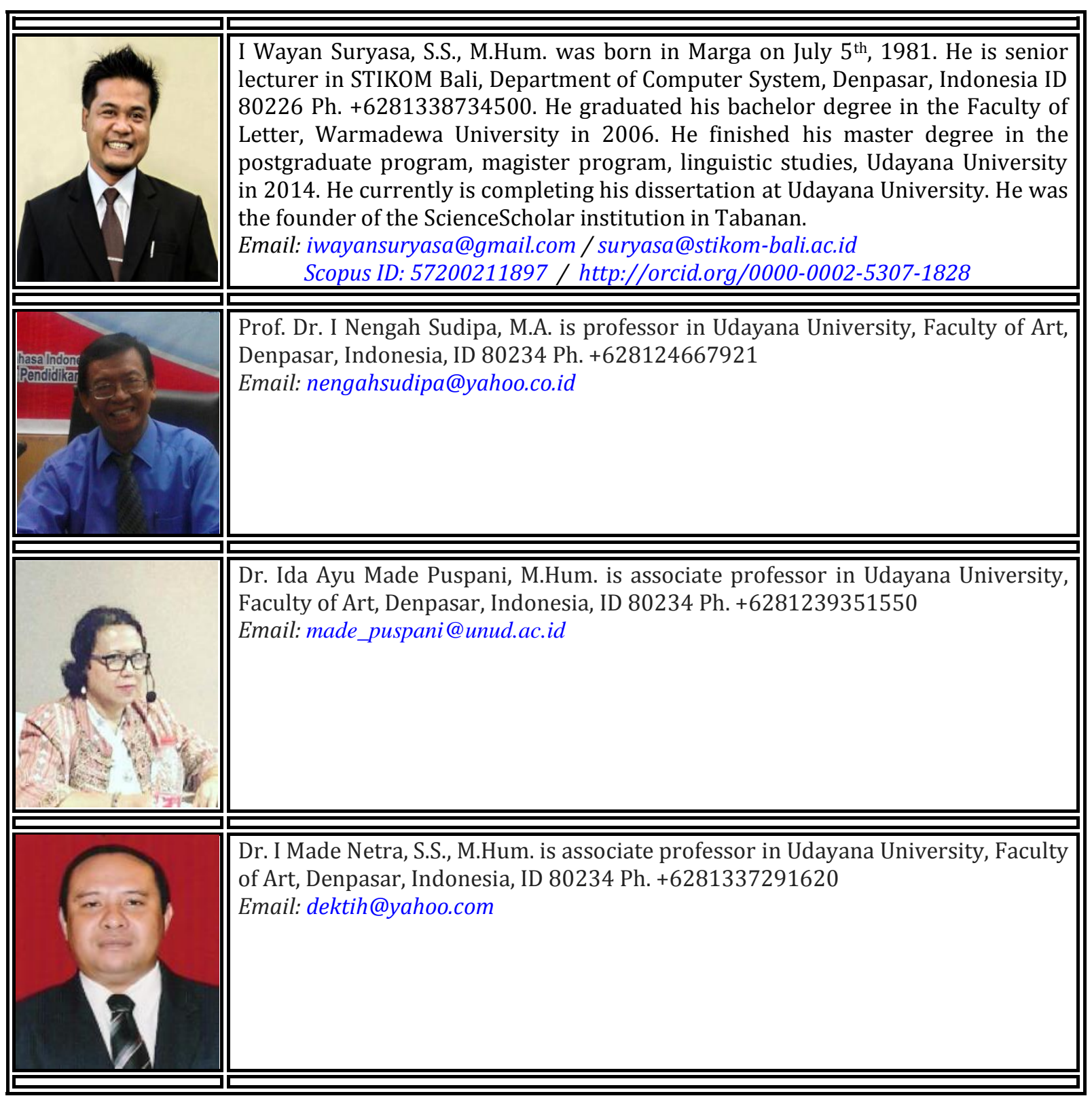

Suryasa, I. W., Sudipa, I. N., Puspani, I. A. M., \& Netra, I. M. (2019). Translation of Krșna Text and Ideology. International Journal of Social Sciences and Humanities, 3(1), 36-47. https://doi.org/10.29332/ijssh.v3n1.251 